\title{
PENGARUH INTELLECTUAL CAPITAL TERHADAP KINERJA PERUSAHAAN ASURANSI DI INDONESIA
}

\author{
Henny Setyo Lestari \\ Fakultas Ekonomi dan Bisnis Universitas Trisakti \\ E-mail: henny_setyo_lestari@trisakti.ac.id
}

\begin{abstract}
The purpose of this paper is to analyze the role of intellectual capital (IC) and its relationship with financial performance of Indonesian Insurance during the period 2003-2012. In total, 11 insurance companies were selected as the sample. Regression model (partial least squares) has been applied to examine the relationship between IC and companies return on assets ratio (ROA). The results of the research revealed that Value added capital coefficient (VACA) have a significantly negative effect and value added human capital (VAHU) has a positive significant effect on the performance of the company (ROA), while the value added of structural capital (SCVA), firm size and financial leverage does not have a significant effect on company performance (ROA). Value added human capital (VAHU) and financial leverage has a positive significant effect on the performance of the company (ROE), while the Value Added Capital Coefficient (VACA), Value Added Structural Capital (SCVA) and firm size has no significant effect on company performance (ROE).
\end{abstract}

Keywords: Insurance Companies, Value added, Intellectual Capital, Financial Performance

\begin{abstract}
Abstrak: Tujuan dari penulisan ini adalah untuk menganalisis peran intellectual capital (IC) dan hubungannya dengan kinerja keuangan Asuransi Indonesia selama periode 20032012. Secara total, 11 perusahaan asuransi terpilih sebagai sampel. Model regresi (kuadrat terkecil parsial) telah diterapkan untuk menguji hubungan antara rasio imbal hasil (ROA) IC dan perusahaan. Hasil penelitian menunjukkan bahwa nilai tambah modal koefisien (VACA) berpengaruh secara signifikan negatif dan nilai tambah human capital (VAHU) berpengaruh positif signifikan terhadap kinerja perusahaan (ROA), sedangkan nilai tambah modal struktural SCVA), ukuran perusahaan dan financial leverage tidak berpengaruh signifikan terhadap kinerja perusahaan (ROA). Nilai tambah human capital (VAHU) dan financial leverage berpengaruh positif signifikan terhadap kinerja perusahaan (ROE), sedangkan Value Added Capital Coefficient (VACA), Value Added Structural Capital (SCVA) dan ukuran perusahaan tidak berpengaruh signifikan terhadap kinerja perusahaan (ROE).
\end{abstract}

Kata kunci: Perusahaan Asuransi, Nilai Tambah, Modal Intelektual, Kinerja Keuangan

\section{PENDAHULUAN}

Untuk mempertahankan keunggulan kompetitif perusahaan, sebaiknya perusahaan meningkatkan kualitas dari sumber daya manusia perusahaan tersebut. Sumber daya utama perusahaan tidak hanya mencakup sumber daya yang berwujud, tetapi juga yang tidak berwujud yang langka, tidak ternilai harganya, tidak tergantikan dan tidak berujung. Selain 
itu, dua faktor utama yang menyebabkan peningkatan kinerja perusahaan dibandingkan dengan dua dekade terakhir adalah globalisasi dan kemajuan teknis. Dengan kondisi tersebut, aset tidak berwujud dan intellectual capital adalah dua faktor kunci dalam keberhasilan perusahaan. Intellectual Capital bersama dengan financial capital dianggap sebagai faktor utama dari profitabilitas perusahaan. Studi penelitian telah mengungkapkan bahwa 50-90 persen dari nilai yang diciptakan bagi perusahaan dalam ekonomi adalah karena Intellectual Capital ketimbang produksi dan penjualan (Enrhardt, 2007). Industri keuangan adalah industri pengetahuan intensif dimana aktivitasnya lainnya menggunakan intellectual capital dibandingkan dengan aset fisik dalam bisnis manufaktur. Salah satu industri moneter adalah perusahaan asuransi (Anshori dan Iswati, 2007). Dengan demikian, dalam penelitian ini, dengan mengukur Intellectual capital dan komponennya menggunakan Value Added Intellectual Coefficient (VAIC), hubungan antara Intellectual Capital dan profitabilitas perusahaan asuransi. VAIC adalah salah satu metode yang paling penting untuk mengukur intellectual capital, karena itu mencerminkan nilai yang diciptakan dalam badan usaha dan umumnya, di perusahaan mana koefisien ini lebih tinggi, hal ini menunjukkan bahwa perusahaan-perusahaan telah berhasil menciptakan nilai potensi (Pullic, 2000).

Ting dan Lean (2009) dalam penelitian yang telah dilakukan memaparkan bahwa dalam era baru dalam bidang ekonomi sekarang ini tentu saja sangat dibutuhkan adanya kemampuan inovasi yang lebih dari sumber daya manusia yang ada untuk mendukung perkembangan perusahaan, yang mana nantinya akan lebih berkelanjutan dan sulit untuk diikuti oleh para pesaing. Pada saat ini khususnya di Asia bahkan di Indonesia sangat jarang dilakukan penelitian mengenai intangible asset. Dalam hal ini penggunaan intellectual capital untuk mengukur tingkat kinerja perusahaan. Seperti yang telah dibahas diatas bahwa intellectual capital merupakan salah satu faktor yang lebih secara real untuk megukur tingkat kinerja perusahaan, karena adanya 'nilai' yang unik dalam intellectual capital tersebut dalam hal ini adalah aset yang tidak berwujud. Berdasarkan latar belakang masalah diatas terlihat jelas bahwa intellectual capital merupakan nilai penting bagi penciptaan nilai perusahaan.

\section{KAJIAN TEORI}

Asuransi. Berdasarkan UU No. 2 Tahun 1992 tentang Usaha Perasuransian definisi asuransi atau pertanggungan adalah perjanjian antara dua pihak atau lebih, dengan mana pihak penanggung mengikatkan diri kepada tertanggung dengan menerima premi untuk memberikan penggantian kepada tertanggung karena kerugian, kerusakan atau kehilangan keuntungan yang diharapkan atau tanggung jawab hukum kepada pihak ketiga yang mungkin akan diderita tertanggung, yang timbul dari suatu peristiwa yang tidak pasti. Objek asuransi adalah benda dan jasa, jiwa dan raga, kesehatan manusia, tanggung jawab hukum, serta semua kepentingan lainnya yang dapat hilang, rusak, rugi, atau berkurang nilainya.

Usaha asuransi mempunyai sifat dan karakteristik yang berbeda dengan jenis usaha di bidang jasa pada umumnya, karena usaha asuransi mengambil alih berbagai risiko dari pihak lain sehingga perusahaan asuransi menjadi padat risiko apabila tidak dikelola dengan baik. Di samping itu, perusahaan asuransi juga padat informasi dengan berbagai informasi yang harus diolah untuk pengambilan keputusan underwriting, keuangan dan 
lain-lain. Dasar usaha asuransi adalah kepercayaan masyarakat, terutama dalam kemampuan keuangan perusahaan untuk memenuhi kewajiban klaim dan kewajiban lainlain tepat pada waktunya. Untuk itu usaha asuransi harus dikelola secara profesional, baik dalam pengelolaan risiko maupun dalam pengelolaan keuangan.

Tugas perusahaan asuransi adalah menghimpun dana-dana yang masuk. Dana-dana yang telah terhimpun tersebut diinvestasikan agar produktif. Kegiatan investasi yang dilakukan oleh perusahaan asuransi disamping menunjang pembangunan nasional juga dapat menekan biaya asuransi, dimana dengan adanya profit atau keuntungan yang diperoleh melalui investasi dana, maka unsur prosentase keuntungan yang diperhitungkan dalam penetapan premi dapat dikurangi. Investasi terdiri dari deposito berjangka, saham, baik yang diperdagangkan di bursa efek maupun tidak dan penyertaan saham serta properti investasi.

Intellectual Capital. Intellectual capital merupakan suatu aset yang secara alami tidak nyata, yang saat ini dinyatakan sebagai suatu aset utama perusahaan dalam bentuk strategi yang dapat meningkatkan kemampuan perusahaan dalam bersaing dan dapat meningkatkan kinerja kuangan hingga ke tingkat yang superior (Chen et.al, 2005). Intellectual capital didefinisikan sebagai aset perusahaan yang berbasis pengetahuan, yang dapat diolah untuk menciptakan nilai bagi perusahaan (Sangkala, 2006).

Bergerak menuju masyarakat berbasis pengetahuan adalah sebuah isu yang telah banyak dibahas hari ini. Munculnya teknologi informasi dan komunikasi dan peliputan di semua aspek kehidupan manusia telah memberikan paradigma baru dan telah menyebabkan sebuah revolusi dalam kehidupan manusia. Perusahaan tidak terkecuali dan mereka memiliki perubahan besar yang berpengalaman dan pengembangan. Selain itu, konsep keunggulan kompetitif telah dibentuk menggunakan pengetahuan perusahaan, ideide ekonomi baru, ide-ide organisasi, dan intellectual capital (Despres dan Chauvel, 1999).

Sejumlah kontribusi teoritis dan praktis, menguraikan pentingnya pengetahuan dan sumber daya tak berwujud bagi peningkatan kinerja perusahaan, telah dihasilkan. Tentu saja, hari ini, intellectual capital disamakan dengan aset pengetahuan (Marr et al, 2004). Selain itu, intellectual capital termasuk aset tidak berwujud, yang tidak dilaporkan dalam laporan keuangan badan usaha (Fornell, 2000; Schiuma et al, 2008 ) sementara 80 persen atau bahkan lebih dari 80 persen dari nilai pasar perusahaan tergantung pada intellectual capital (Fornell, 2000). Yang menggunakan istilah intellectual capital pertama kali adalah ekonom John Kenneth. Stewart (1997) mendefinisikan intellectual capital sebagai koleksi pengetahuan, informasi, hak kekayaan intelektual dan pengalaman dari setiap individu dalam suatu badan usaha. Namun, ada satu definisi yang lebih komprehensif, intellectual capital mengacu pada jumlah seluruh saham perusahaan yang memanfaatkan pengetahuan untuk keunggulan kompetitif. Menurut penafsiran baru dari intellectual capital, intellectual capital didefinisikan sebagai kelompok aset pengetahuan yang dimiliki dan atau dikendalikan oleh suatu organisasi dan yang paling penting mengarahkan organisasi nilai mekanisme penciptaan untuk pemangku kepentingan utama perusahaan yang ditargetkan. Adopsi konsep aset pengetahuan untuk menjelaskan komponen Intellectual Capital memungkinkan untuk mempertimbangkan sebagai sumber pengetahuan tidak hanya aset tidak berwujud organisasi, tetapi juga orang-aset berwujud menggabungkan aset pengetahuan dan pengetahuan di dasar kompetensi organisasi. Dibandingkan dengan sumber daya nyata dari perusahaan, investasi yang berkaitan dengan 
intellectual capital dan efisiensi mereka tidak dapat ditentukan dan dilaporkan dalam laporan keuangan. Jadi dengan mengukur intellectual capital, dapat dianggap sebagai konseptualisasi jawaban yang lebih baik untuk kebutuhan manajer untuk memiliki gagasan operasi sumber daya perusahaan kognitif dan tidak berwujud. Selain itu, itu merupakan faktor penting untuk meningkatkan pengetahuan dan mendukung peningkatan kinerja yang berkesinambungan dalam organisasi. Meskipun belum ada konsensus dalam literatur pada dimensi intellectual capital, banyak penulis menganggap ada tiga dimensi, human capital, relational capital dan structural capital. Reed et al. (2006) dan Subramaniam dan Youndt (2005) mengadopsi klasifikasi yang sama, mengusulkan bahwa intellectual capital terdiri dari tiga komponen dasar yaitu human, organisational dan social capital.

Menurut Schiuma et al. (2008), intellectul capital dipecah menjadi lima bagian yaitu:

1. Human Capital. Seperti aset lainnya, individu yang bekerja di perusahaan dianggap sebagai sumber daya kompetitif strategis dan diinvestasikan pada aset tidak berwujud seperti, human capital adalah bagian utama dari intellectual capital (Moon dan Kym, 2006). Human Capital meliputi pengetahuan, pengalaman, dan keterampilan khusus dari personil dari badan usaha yang digunakan untuk menciptakan nilai ekonomi (Cohen dan Kaimenakis, 2007). Menurut Schiuma et al (2008) dapat dianggap sebagai pengetahuan, keterampilan, kecerdasan, hubungan, sikap, bakat, dan perilaku karyawan. Sesuai dengan interpretasi ini, human capital adalah konsep holistik, yang menunjukkan sumber daya organisasi dan aset yang berkaitan dengan orang perusahaan. Selain itu, sumber daya dan aset menentukan nilai perusahaan, dari sudut pandang statis, dan juga merupakan faktor kunci operasi penting untuk mendukung dan mendorong dinamika penciptaan nilai dari waktu ke waktu

2. Relational Capital. Relational capital mencerminkan nilai yang terkait dengan badan usaha, yang diciptakan melalui hubungan antara organisasi dan peraturan badan usaha, serta hubungan dengan pemasok potensial, pemegang saham, dan individu lainnya. Secara umum, terdiri dari hubungan antara organisasi dan masyarakat (Grasenick dan Low, 2004). Kualitas hubungan dan kemampuan untuk menciptakan pelanggan baru merupakan faktor kunci bagi keberhasilan suatu perusahaan (Montequin et al, 2006). Selain itu, relational capital termasuk hubungan dengan pelanggan dan pemerintah dan mengacu pada pengembangan dan pemeliharaan hubungan penting seperti mereka dengan pelanggan dan pemasok barang dan jasa, serta tingkat kepuasan mitra dan loyalitas pelanggan (Chu et al, 2006)

3. Organitational Capital. Roos dan Roos (1997) mengklasifikasikan organitational capital sebagai aset penting yang meliputi produksi atau proses lainnya, spesialisasi, dan arus informasi. Di sisi lain, itu adalah seperangkat berwujud (eksplisit dan implisit, formal dan informal) ditandai sebagai pengetahuan sosial atau kolektif (Bueno et al,2007). Selain itu, struktur ini mengembangkan kegiatan yang efektif dan efisien dari organisasi (Canizares et al, 2007). Organitational capital cenderung untuk tidak hanya membentuk pola sistem perilaku dan interpretasi (Crossan et al, 1999; Kim,1993), tetapi juga menyediakan mekanisme penting untuk mengintegrasikan dan menggabungkan pengetahuan menjadi pengetahuan organisasi (Grant, 1996)

4. Structural Capital. Structural capital dibagi menjadi teknologi dan organisasi dan kadang-kadang disebut sebagai organitational capital (Mouritsen et al, 2001). Structural Capital mencakup semua sumber diluar pengetahuan manusia dalam organisasi. Hal ini terkait dengan proses yang dimiliki oleh organisasi dan dukungan 
human capital (Watson dan Stanworth, 2006). Structural capital didefinisikan sebagai sistem umum dan prosedur untuk memecahkan masalah dan inovasi (Chu et al, 2006). Selanjutnya, structural capital menunjukkan komposisi dan struktur organisasi yang mengarah pada penciptaan pengetahuan dan pengembangan serta penyebaran pengetahuan yang diciptakan. Structural capital terdiri dari keterampilan dan kemampuan individu yang digunakan dalam struktur organisasi (Pablos, 2005). Selain itu, sumber daya tersebut menggambarkan pengetahuan yang telah diperoleh dan dikumpulkan dalam struktur, proses, dan budaya organisasi.

5. Social Capital. Social Capital mengakui pentingnya hubungan sosial dan dipahami sebagai jaringan dengan norma bersama, nilai-nilai, dan pemahaman yang memfasilitasi kerjasama dalam atau antar kelompok (OECD, 2001). Ini adalah kekuatan tak terlihat tertanam dalam hubungan individu, organisasi, masyarakat atau pelaku ekonomi yang mendukung pertumbuhan dan menyediakan saluran bagi pertukaran pengetahuan dan kombinasi dalam organisasi (Kang dan Snell, 2009). Social Capital, sebagai satu kelompok aset, yang berperanan penting dalam mendefinisikan dan menciptakan nilai dari setiap sistem organisasi (Schiuma et al, 2008).

6. Stakeholder Capital. Intellectual Capital telah didekomposisi menjadi konsep anak perusahaan seperti struktural capital, human capital, relational capital, stakeholder capital dan knowledge capital untuk tujuan pengukuran dan pelaporan untuk manajemen. Stakeholder capital juga merupakan bagian dari structural capital. Stakeholder capital ini merupakan beberapa bentuk dari structural capital yang karena pentingnya dalam kesuksesan suatu perusahaan, maka ditangani secara terpisah dari konsep yang lebih luas dari structural capital (Schiuma et al, 2008).

Value Added Intellectual Coefficint (VAIC). Suatu perusahaan yang ingin memperoleh kesuksesan dalam mengelola intellectual capital maka perusahan harus memiliki metode dalam mengukur nilai intellectual capital yang memiliki kontribusi untuk penciptaan nilai, memungkinkan untuk dilakukan perbandingan dan mengaplikasikan tindakan korektif. Value Added Intellectual Coefficient sebagai pengukuran dari intellectual capital perusahaan dimana intellectual capital perusahaan dapat memberikan dampak pada investor dalam memperoleh capital gain per lembar saham (Firer dan Williams, 2003). Goh (2005) mengatakan bahwa value added intelellectual capital (VAIC) merupakan metode yang dirancang untuk memungkinkan suatu organisasi dalam mengukur intellectual capital suatu perusahaan sehingga dapat menjadi faktor penentu suksesnya suatu bisnis pada masa sekarang ini.

Sesuai dengan penelitian yang dilakukan oleh Kamath (2007), menjelaskan bahwa sebab utama VAIC digunakan untuk mengukur kinerja perusahaan adalah: (1) Karena potensi intelektual di suatu perusahaan merupakan sumber daya yang penting untuk kesuksesan perusahaan tersebut; (2) Karena untuk mencapai efisiensi intelektual tersebut sangat sederhana dan merupakan cara yang aman untuk menjamin pencapaian kesuksesan dalam perusahaan; (3) Karena Value Added Intellectual Capital sudah membuktikan kepatutannya sebagai alat untuk mengukur intellectual capital suatu perusahaan; (4) Adanya fakta bahwa perusahaan-perusahaan memiliki biaya yang lebih tinggi pada kemampuan intelektual daripada physical capitalnya dan bahwa dengan VAIC dapat ditemukan indikasi yang terpercaya untuk kemampuan intelektualnya, adalah alasan yang 
sangat baik untuk memberikan perhatian yang lebih tinggi pada potensi intelektual tersebut.

Kinerja Perusahaan. Kinerja perusahaan merupakan suatu hasil atau prestasi yang telah dicapai oleh perusahaan dalam menjalankan fungsinya dan pengelolaan perusahaan selama periode tertentu. Tujuannya adalah untuk memperoleh kepercayaan dari masyarakat, pihak luar dan pemerintah. Dalam proses menjalankan usahanya, perusahaan harus bisa menjaga kinerja perusahaannya. Kinerja perusahaan ini dapat dilihat dari berbagai macam aspek yang mempengaruhi, baik dari aspek keuangan maupun aspek operasional.

Jika dilihat dari aspek keuangan, hal-hal yang perlu diperhatikan untuk dapat menilai apakah suatu perusahaan tersebut baik atau buruk adalah dengan melihat arus kas, laporan keuangan, laporan laba/rugi dan neraca keuangannya. Jika dilihat dari aspek operasionalnya, maka hal-hal yang perlu diperhatikan adalah operasional perusahaan itu sendiri, yaitu jumlah karyawan, sarana dan prasarana yang digunakan untuk menunjang kegiatan operasional perusahaan tersebut.

Kinerja keuangan perusahaan diperlukan untuk menilai perubahan potensial sumber daya ekonomi suatu perusahaan pada masa yang akan datang dan bermanfaat untuk mengukur tingkat kemampuan perusahaan dalam meningkatkan nilai (value) perusahaan dan memaksimumkan kesejahteraan para pemegang saham perusahaan tersebut. Keberhasilan suatu perusahaan dalam memaksimumkan kesejahteraan para pemegang saham perusahaan tersebut dapat dilihat dan dianalisa dari laporan keuangan perusahaan.

Kinerja keuangan perusahaan dapat diartikan sebagai kondisi suatu perusahaan. Untuk dapat memperoleh gambaran yang jelas tentang perkembangan kinerja perusahaan, maka perlu dilakukan proses analisa terhadap data keuangan dari perusahaan tersebut dan data keuangan itu akan tercermin dalam laporan keuangan perusahaan tersebut.

Menurut Gitman dan Zutter (2015) terdapat 5 kategori rasio keuangan perusahaan yang digunakan untuk menilai kinerja keuangan perusahaan, adalah sebagai berikut: (1) Liquidity Ratio. Rasio yang menunjukkan kemampuan perusahaan untuk memenuhi kewajiban jangka pendeknya pada saat jatuh tempo; (2) Activity Ratio. Rasio ini digunakan untuk mengukur kecepatan suatu account untuk dapat dikonversi menjadi penjualan atau kas; (3) Debt Ratio. Rasio hutang digunakan untuk mengetahui besarnya proporsi Total Asset yang dibiayai dengan hutang; (4) Profitability Ratio. Rasio pengukuran ini mengevaluasi keuntungan perusahaan terhadap tingkat penjualan tertentu, tingkat aset tertentu, investasi dari pemilik maupun nilai saham; (5) Market Ratio. Rasio ini berhubungan dengan nilai pasar sebuah perusahaan, yang diukur dengan harga saham saat ini

Arti pentingnya kinerja keuangan seperti yang dikemukakan oleh Brigham dan Houston (2010) adalah sebagai berikut: (1) Alat skrinning awal dalam pemilihan investasi; (2) Alat perkiraan terhadap hasil dan kondisi keuangan perusahaan; (3) Alat diagnosis terhadap masalah manajerial, operasional atau masalah-masalah lainnya; (4) Alat untuk menilai manajemen perusahaan

Kinerja Keuangan perusahaan dapat dirumuskan sebagai perbandingan antara nilai yang dihasilkan oleh suatu perusahaan dengan menggunakan asetnya yang produktif dan nilai yang diharapkan dari pemilik aset tersebut. Untuk menilai kinerja perusahaan perlu dikaitkan dengan kinerja keuangan kualitatif dan ekonomi.

Kinerja keuangan perusahaan dihasilkan dari beberapa keputusan individual yang dilakukan secara berkesinambungan oleh manajemen. Jadi dapat disimpulkan bahwa 
kinerja keuangan perusahaan bermanfaat dalam memprediksi kapasitas perusahaan dalam menghasilkan arus kas dari sumber daya yang dimiliki perusahaan. Pada dasarnya, kinerja keuangan perusahaan merupakan tingkat keberhasilan perusahaan yang dapat diukur dari efektifitas dan efisiensi perusahaan secara keseluruhan.

Return on Assets (ROA). Return on Asset (ROA) menunjukkan seberapa besar kemampuan perusahaan dalam menghasilkan laba bersih yang dapat diperoleh dari seluruh aset yang dimiliki perusahaan. Return on Assets ini merupakan jenis rasio yang menjelaskan seberapa efisiensi perusahaan untuk dapat memanfaatkan atau menggunakan asetnya yang tersedia untuk dapat menghasilkan keuntungan. Semakin tinggi nilai ROA suatu perusahaan semakin menunjukkan kinerja perusahaan yang baik (Gitman dan Zutter, 2015). Menurut Firer dan Williams, 2003; Chen et al, 2005 dengan menggunakan rasio Return on Assets ini, maka kita dapat mengevaluasi kinerja perusahaan dan mencerminkan tingkat efisiensi dalam menggunakan aset untuk mendapatkan keuntungan.

Return on Equity (ROE). Menurut Gitman dan Zutter (2015), Return on Equity dapat mengukur pendapatan perusahaan terhadap investasi para pemegang saham secara umum serta menggambarkan kemampuan perusahaan mendapatkan laba melalui semua kemampuan dan sumber yang ada seperti kegiatan penjualan, kas, modal, jumlah karyawan, jumlah cabang dan sebagainya. Keuntungan yang akan diraih dari investasi yang akan ditanamkan merupakan pertimbangan utama bagi sebuah perusahaan dalam rangka pengembangan bisnisnya.

Menurut Taswan (2010), Return on Equity merupakan rasio yang mengukur kemampuan perusahaan dalam menghasilkan net income dari sudut equity capitalnya. Dengan demikian dapat disimpulkan bahwa return on equity adalah rasio yang memperlihatkan kemampuan modal sendiri dalam memaksimalkan keuntungan.

Return on Equity adalah apa yang pemegang saham lihat sebagai imbalan atas investasi mereka. Sebuah bisnis yang memiliki return on equity lebih menjadi acuan bahwa perusahaan mampu menghasilkan kas secara internal. Dengan demikian, semakin tinggi Return on Equity semakin baik perusahaan dalam hal mendapatkan keuntungan. Hal ini dijelaskan lebih lanjut oleh Khrawish (2011) bahwa Return on Equity adalah rasio laba bersih setelah pajak dibagi dengan total equity. Semakin tinggi Return On Equity semakin efektif manajemen dalam memanfaatkan modal pemegang saham.

Ukuran Perusahaan (Firm Size). Firm size merupakan salah satu tolak ukur perusahaan untuk memastikan bahwa seberapa besar dapat menguasai pangsa pasar dan memperoleh keuntungan yang dihitung berdasarkan banyaknya total assets yang dimiliki. Selain itu Firm Size juga digunakan untuk menggambarkan dampak ukuran perusahaan terhadap kinerja perusahaan.

Menurut Charumathi (2012), perusahaan asuransi dengan skala besar memiliki keuntungan yang lebih dan tingkat pengembalian aset yang tinggi dibandingkan perusahaan kecil. Perusahaan besar memiliki kekuatan lebih kompetitif bila dibandingkan dengan perusahaan kecil di bidang yang membutuhkan persaingan. Karena mereka memiliki pangsa pasar yang lebih besar, perusahaan besar memiliki kesempatan untuk mendapatkan keuntungan lebih.

Firm size cenderung mencerminkan penilaian pemegang saham atas keseluruhan aspek dari financial performance di masa lampau dan prakiraan di masa yang akan datang. Semakin besarnya aset perusahaan akan membuat perusahaan memiliki kestabilan dalam 
kondisi keuangannya sehingga akan lebih mudah dalam memperoleh modal dibandingkan dengan perusahaan yang memiliki aset yang lebih rendah (Almajali et al, 2012).

Dalam pengelolaan aset yang dilakukan oleh perusahaan besar dapat mendorong terciptanya skala ekonomis dan efisiensi dalam proses produksi jika dibandingkan dengan perusahaan yang lebih kecil yang memiliki keterbatasan dalam aset yang dimiliki. Hal ini berarti biaya yang dikeluarkan lebih rendah bagi perusahaan besar karena perusahaan dapat mempertahankan keuntungan yang lebih tinggi jika perusahaan tidak beroperasi dalam lingkungan yang sangat kompetitif (Flamini et al, 2009).

Penelitian yang dilakukan oleh Mehari dan Aemiro (2013) menyatakan bahwa ukuran perusahaan secara positif terkait dengan kinerja keuangan. Alasan utama di balik pernyataan ini yaitu pertama, perusahaan asuransi yang besar biasanya memiliki kapasitas yang lebih besar untuk menangani fluktuasi yang merugikan pasar dibandingkan perusahaan asuransi kecil. Kedua, perusahaan asuransi besar biasanya dapat dengan mudah merekrut karyawan dengan pengetahuan profesional dibandingkan dengan perusahaan asuransi kecil. Ketiga, perusahaan asuransi besar memiliki skala ekonomi dalam hal biaya tenaga kerja, yang merupakan faktor produksi yang paling signifikan untuk memberikan layanan asuransi. Begitu juga penelitian yang dilakukan oleh Ahmed et al (2011) menemukan adanya pengaruh positif signifikan antara ukuran perusahaan dan financial performance. Firm size diukur dengan menggunakan total assets perusahaan.

Leverage. Leverage tercipta dari penggunaan aset maupun dana, dalam rangka upaya meningkatkan keuntungan bagi pemilik perusahaan. Dalam konteks manajemen keuangan, yang dimaksud dengan leverage adalah dana yang menanggung beban atau biaya tetap, baik dana yang berupa real asset maupun financial asset. Aset atau sumber dana adalah bertindak sebagai kekuatan untuk meningkatkan kemampuan perusahaan untuk meningkatkan profitabilitas. Semakin besar leverage maka akan semakin besar pula fluktuasi keuntungan, yang berarti besar pula resiko (Gitman dan Zutter, 2015).

Menurut Mehari dan Aemiro (2013), leverage merupakan rasio keuangan yang mengindikasikan persentase aset perusahaan yang didanai oleh pinajaman. Dalam penelitian yang dilakukannya ditemukan bahwa terdapat hubungan positif antara leverage terhadap financial performance asuransi. Hal ini memberikan bukti bahwa perusahaan asuransi dengan leverage yang tinggi memiliki kinerja operasional yang lebih baik daripada perusahaan asuransi dengan leverage yang rendah.

Menurut Almajali et al (2012), perusahaan yang sangat leverage mungkin menghadapi risiko kebangkrutan jika mereka tidak mampu untuk melakukan pembayaran utang mereka, mereka juga mungkin tidak dapat menemukan pemberi pinjaman baru di masa depan. Namun leverage tidak selalu buruk, karena dapat meningkatkan laba pemegang saham atas investasi mereka dan memanfaatkan keuntungan pajak yang terkait dengan pinjaman. Dalam penelitian yang dilakukan, leverage diukur dengan rasio total utang terhadap ekuitas (debt ratio/equity). Hasil penelitian menjelaskan bahwa terdapat pengaruh positif antara leverage terhadap financial performance. Hal ini menjelaskan bahwa leverage yang tinggi mungkin bermanfaat, karena dapat meningkatkan insentif manajerial.

Menurut Khrawish dan Khraiwesh (2010), rasio ini menunjukkan hubungan antara total kewajiban dengan total aset. Memilih ukuran ini disebabkan oleh fakta bahwa menggunakan utang untuk keperluan dalam struktur pendanaan merupakan insentif dan sasaran bagi banyak perusahaan untuk meningkatkan laba atas investasi mereka. 
Perusahaan asuransi dapat menjadi makmur dengan mengambil risiko pinjaman yang wajar atau dapat menjadi bangkrut jika risiko berada di luar kendali.

Namun, menurut hasil penelitian Ahmed et. al (2011) menyatakan bahwa penggunaan hutang dalam porsi yang tinggi memiliki dampak kerugian. Perusahaan dengan tingkat hutang yang tinggi, menyebabkan meningkatnya risiko dari financial distress perusahaan. Hal ini akan mengarah kepada modal investasi jangka panjang yang lebih rendah sehingga pada akhirnya akan mengakibatkan financial performance yang rendah. Selain itu, jika tingkat pengembalian yang akan didapat perusahaan dari penggunaan hutang tersebut lebih kecil dari biaya yang harus dikeluarkan atas penggunaan hutang tersebut maka penggunaan hutang itu tidak menguntungkan bagi perusahaan dan dapat mengurangi keuntungan yang didapat perusahaan.

Intellectual Capital dapat digambarkan sebagai bentuk aset perusahaan yang tidak berwujud yang dapat diciptakan oleh perusahaan itu sendiri dengan menggunakan segala asset yang dimiliki oleh perusahaan dengan maksimal dan efisien, serta didukung dengan kemampuan intellectual yang dimiliki karyawannya yang harus dikembangkan oleh perusahaan melalui program-program pembelajaran (Bontis et. al, 2000). Intellectual capital diakui sebagai aset strategis yang dapat memberikan keuntungan kompetitif dengan mengarahkan perusahaan memperoleh kinerja yang unggul berbasis pengetahuan ekonomi di zaman modern. Vallue Added Intellectual Capital (VAIC) merupakan salah satu metode yang digunakan untuk mengukur intellectual capital yang terdiri dari tiga komponen utama seperti yang dikatakan oleh Pulic (1998) yaitu Value Added Capital Coefficient (VACA) yang berupa teknologi canggih, Value Added Human Capital (VAHU) yang berupa pengetahuan dan wawasan karyawan, Value Added Structural Capital (SCVA) yang berupa struktur organisasi atau pembagian tugas karyawannya.

Intellectual capital berpengaruh secara signifikan terhadap kinerja perusahaan dan diyakini dapat berperan penting dalam peningkatan nilai perusahaan maupun kinerja perusahaan yang dijelaskan bahwa intellectual capital memainkan peran penting dalam menghemat biaya produksi perusahaan. Untuk pengaruh Value Added Intellectual Capital Coefficient terhadap kinerja keuangan menjelaskan bahwa intellectual capital dapat menghasilkan laba suatu perusahaan (Zeghal dan Maaloul, 2010). Sehingga indikator yang digunakan untuk menilai kinerja perusahaan dengan menggunakan 2 ukuran kinerja perusahaan yaitu Return On Asset (ROA) dan Return On Equity (ROE) yang merupakan pengukuran yang mengukur profitabilitas di dalam perusahaan.

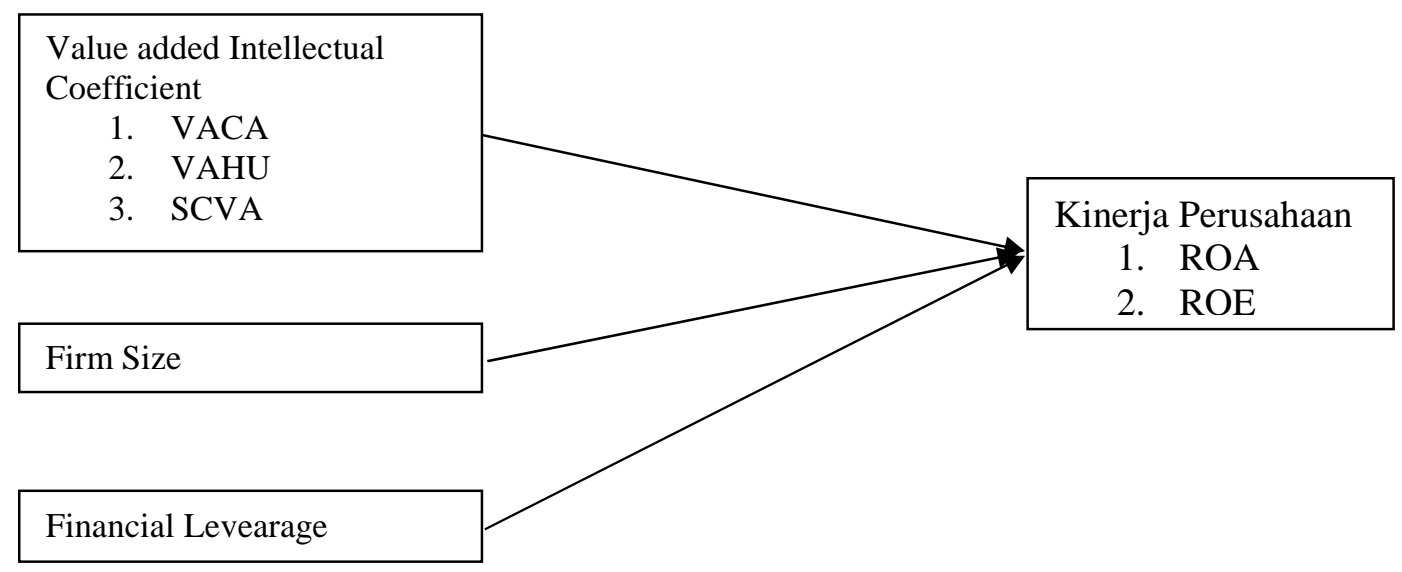

Gambar 1. Rerangka Konseptual 
Hipotesa. Hasil penelitian yang dilakukan oleh Ting dan Lean (2009), dimana mereka menemukan bahwa terdapat pengaruh yang positif dari Value Added Intellectual Coefficient (VAIC) yang diikuti oleh Value Added Human Capital (VAHU), Value Added Structural Capital (SCVA) dan Value Added Capital Employed VACA) terhadap tingkat kinerja dari perusahaan melalui tingkat keuntungan perusahaan yang diukur dengan Return On Assets. Hasil penelitian Firer dan Williams (2003), penelitian dilaksanakan di Afrika Selatan dengan Return On Assets (ROA), Productivity Performance (ATO) dan Market Valuation $(M B)$ sebagai indikator kinerja perusahaan mengindikasikan bahwa hubungan antara efisiensi value added dari sumber daya utama perusahaan yaitu profitability, productivity dan market valuation secara umum terbatas dan tidak konsisten, dapat dinyatakan bahwa capital employed merupakan faktor yang paling signifikan dan berpengaruh terhadap tingkat profitabilitas di Afrika Selatan. Kamath (2007) dalam penelitiannya di India menemukan bahwa value added capital employed (VACA) memiliki pengaruh yang cukup signifikan terhadap tingkat profitabilitas perusahaan. Sedangkan penelitian yang dilakukan oleh Cabrita dan Bontis (2008) menunjukkan bahwa secara signifikan value added human capital (VAHU) memiliki pengaruh positif terhadap tingkat keuntungan dari perusahaan. Dengan demikian maka, hipotesis dalam penelitian ini adalah sebagai berikut:

H1: Terdapat pengaruh signifikan antara komponen Value Added Intellectual Coefficient terhadap kinerja perusahaan

Chen et. al (2005) mengatakan bahwa jika sumber daya intelektual sebagai sumber daya yang sangat bernilai untuk keuntungan kompetitif perusahaan yang akan memberikan kontribusi terhadap kinerja keuangan perusahaan. Hasil penelitian yang dilakukan oleh Kujansivu dan Lonncvist (2007) menunjukkan bahwa secara signifikan terdapat pengaruh intellectual capital terhadap tingkat keuntungan atau tingkat profitabilitas dari perusahaan tersebut. Zeghal dan Maaloul (2010) menunjukkan bahwa value added intellectual coefficient terdapat pengaruh positif terhadap tingkat profitabilitas perusahaan. Dengan demikian maka, hipotesis dalam penelitian ini adalah sebagai berikut:

H2: Terdapat pengaruh signifikan antara Value Added Intellectual Coefficient terhadap kinerja perusahaan.

\section{METODE}

Metode penelitian yang digunakan dalam penelitian ini adalah uji hipotesis. Penelitian uji hipotesis ini mencoba untuk menguji hipotesis mengenai hubungan dari intellectual capital dimana pengukurannya menggunakan Value Added Intellectual Capital terhadap Return on Assets dan Return on Equity. Alasan pemilihan metode ini karena metode ini sesuai dengan tujuan penelitian yaitu mengetahui pengaruh Intellectual Capital terhadap kinerja keuangan.

Variabel-variabel dalam penelitian ini meliputi variabel dependen dan variabel independen. Variabel dependen adalah variabel yang nilainya dipengaruhi oleh banyak faktor (variabel independen). Variabel yang digunakan dalam penelitian ini terdiri dari :

Variabel Independen. Variabel independen adalah variabel yang nilainya mempengaruhi perilaku dari variabel terikat (variabel dependen). Variabel independen yang digunakan dalam penelitian ini adalah dengan menganalisis intellectual capital yang diukur dengan menggunakan metode VAIC (Pulic, 2000) dengan rumus sebagai berikut: 


$$
V A I C=V A C A+V A H U+S C V A
$$

1. Value Added Capital Coefficient (VACA)

$$
\mathrm{VACA}=\mathrm{VA} / \mathrm{CA}
$$

Dimana:

$\mathrm{VA}=$ corporate value added

$=$ OUTPUT - INPUT

$=\mathrm{OP}+\mathrm{EC}+\mathrm{D}+\mathrm{A}$

$\mathrm{OP}=$ operational profit

$\mathrm{EC}=$ employee cost

$\mathrm{D}=$ depreciation

$\mathrm{A}=$ amortization

$\mathrm{CA}=$ the capital employed

$=$ the book value of total assets - intangible assets

2. Value Added Human Capital (VAHU)

Dimana:

$$
\text { VAHU }=\text { VA/HU }
$$

$\mathrm{HU}=$ the total employee cost

3. Value Added Structural Capital (SCVA)

Dimana :

$$
\text { SCVA }=\text { SC/VA }
$$

$\mathrm{SC}=$ structural capital

$$
=\mathrm{VA}-\mathrm{HC}
$$

$\mathrm{HC}=$ human capital

\section{Variabel Dependen}

Variabel dependen adalah variabel yang nilainya dipengaruhi oleh banyak faktor (variabel independen). Dalam penelitian ini variabel dependen yang digunakan yaitu pengukuran kinerja perusahaan (Gitman dan Zutter, 2015) dengan cara menghitung :

1. Return on Assets

$$
\text { ROA = Net Income/Total Assets }
$$

2. Return on Equity

$R O E=$ Net Income/Total Equity 


\section{Variabel Kontrol}

1. Firm Size (FSize)

$$
\text { FSize = Log Natural dari Total Asset }
$$

\section{Financial Leverage}

$$
\text { LEV = Total Liabilities/Total Assets }
$$

Dalam penelitian ini, jenis data yang digunakan adalah data sekunder. Data sekunder adalah data yang telah diolah seperti data hasil penelitian kepustakaan, hasil dokumentasi penelitian dan laporan keuangan yang telah dipublikasikan. Data-data dalam penelitian ini diperoleh dari laporan keuangan pada perusahaan-perusahaan asuransi yang terdaftar di Bursa Efek Indonesia (IDX) periode tahun 2003-2012. Semua data yang diperlukan diperoleh dari website Bursa efek Indonesia (BEI) di alamat www.idx.co.id dan Indonesian Capital Market Directory.

Penelitian ini dilakukan untuk melihat pengaruh Intellectual Capital terhadap kinerja perusahaan. Metode yang digunakan untuk memperoleh sampel dalam penelitian ini adalah dengan purposive sampling, yaitu sampel yang diambil secara acak ditentukan berdasarkan kriteria-kriteria sebagai berikut: (1) Perusahaan-perusahaan asuransi yang terdaftar di Bursa Efek Indonesia yang berjumlah 11 perusahaan; (2) Periode penelitian tahun 2003 sampai dengan 2012; (3) Perusahaan yang dijadikan sampel dalam penelitian ini tetap terdaftar di Bursa Efek Indonesia selama periode penelitian, yaitu tahun 2013 sampai dengan tahun 2012 dan tidak pernah mengalami tidak terdaftar pada tahun tertentu selama terdaftar di Bursa Efek Indonesia.

\section{Metode Analisis Data}

1. Multiple Regresi. Dengan menggunakan metode model regresi linear berganda maka rumus yang akan digunakan adalah sebagai berikut:

Model 1.

$\mathrm{ROA}=\alpha+\beta 1(\mathrm{VACA})+\beta 2(\mathrm{VAHU})+\beta 3(\mathrm{SCVA})+\beta 4(\mathrm{FSize})+\beta 5(\mathrm{LEV})+\varepsilon$

Model 2.

$\mathrm{ROA}=\alpha+\beta 1(\mathrm{VAIC})+\beta 2(\mathrm{FSize})+\beta 3(\mathrm{LEV})+\varepsilon$

Model 3.

$\mathrm{ROE}=\alpha+\beta 1(\mathrm{VACA})+\beta 2(\mathrm{VAHU})+\beta 3(\mathrm{SCVA})+\beta 4(\mathrm{FSize})+\beta 5(\mathrm{LEV})+\varepsilon$

Model 4.

$\mathrm{ROE}=\alpha+\beta 1(\mathrm{VAIC})+\beta 2(\mathrm{FSize})+\beta 3(\mathrm{LEV})+\varepsilon$

2. Uji t (Uji Partial). Pengujian partial dilakukan untuk menguji koefisien regresi dengan melihat signifikansi dari pengaruh masing-masing variabel independen terhadap variabel dependen dengan mengasumsikan variabel lain adalah konstan.

Dasar pengambilan keputusan untuk pengujian secara partial ini adalah sebagai berikut:

a) jika p value $<0.05$ maka Ho ditolak

b) jika $\mathrm{p}$ value $>0.05$ maka Ho diterima 


\section{HASIL DAN PEMBAHASAN}

1. Multiple Regresi

Model 1

ROA $=0,096-0,00005396$ VACA + 0,004 VAHU + 0,005 SCVA - 0,006 FSize + $0,025 \mathrm{LEV}$

Model 2

ROA $=-0,026-0,00000625$ VAIC + 0,006 FSize - 0,011 LEV

Model 3

ROE $=-0,051-0,00007997$ VACA + 0,006 VAHU + 0,039 SCVA - 0,002 FSize + $0,281 \mathrm{LEV}$

Model 4

ROE $=-0,230-0,00005314$ VAIC - 0,018 FSize + 0,21 LEV

2. $\mathrm{Uji} \mathrm{T}$

\section{Model 1}

Tabel 1. Hasil Uji T

Variabel Dependen: ROA

\begin{tabular}{lccc}
\hline \multicolumn{1}{c}{ Variabel Independen } & Koefisien & Sig & Keterangan \\
\hline C & 0,096 & 0,035 & - \\
VACA & 0,00005396 & 0,030 & signifikan \\
VAHU & 0,004 & 0,000 & Signifikan \\
SCVA & 0,005 & 0.621 & tidak signifikan \\
FSize & $-0,006$ & 0.101 & tidak Signifikan \\
Lev & 0,025 & 0.236 & idak Signifikan \\
\hline
\end{tabular}

Dari hasil analisis yang dilakukan dapat disimpulkan bahwa variabel independen yang pertama yaitu Value Added Capital Coefficient (VACA) memiliki pengaruh negatif signifikan terhadap kinerja perusahaan (ROA). Hal ini tidak sesuai dengan hasil penelitian sebelumnya yang dilakukan Kamath (2008) pada Perusahaan Farmasi di India yang mengungkapkan bahwa secara keseluruhan capital employed diukur dengan VACA, yang berkorelasi positif terhadap kinerja perusahaan. Firer dan Williams (2003), menggunakan objek 75 perusahaan sektor bisnis yang telah go public di Afrika Selatan. Mereka mengindikasikan bahwa hubungan antara efisiensi value added dari sumber daya utama perusahaan yaitu profitability, productivity dan market valuation secara umum terbatas dan tidak konsisten dapat dinyatakan bahwa capital employed merupakan faktor yang paling signifikan dan berpengaruh terhadap tingkat profitabilitas di Afrika Selatan.

Hasil penelitian variabel yang kedua yaitu Value Added Human Capital (VAHU) memiliki pengaruh positif terhadap kinerja perusahaan (ROA). Hal ini sesuai dengan studi empiris sebelumnya yang dilakukan secara terpisah oleh (Chen at al, 2005; Kamath, 2008, Cabrita dan Bontis, 2008; Cheng et al, 2010; Chan, 2009) yang menetapkan bahwa komponen seperti Value Added Human Capital (VAHU) yang relatif lebih memainkan peran yang signifikan serta berhubungan dengan kinerja keuangan dan tingkat profitabilitas bila dibandingkan dengan Value Added Structural Capital (SCVA) dan Value Added Capital Coefficient (VACA).

Hasil penelitian variabel independen yang ketiga yaitu Value Added Structural Capital (SCVA) tidak memiliki pengaruh terhadap kinerja perusahaan (ROA). Hasil 
penelitian ini tidak sesuai dengan penelitian yang dilakukan oleh (Bontis, 1998; Bontis et al, 2000) bertujuan untuk menginvestasi tiga elemen Intellectual Capital (IC) yakni Human Capital (HC), Customer Capital (CC) dan Structural Capital (SC) dan hubungannya dengan tingkat keuntungan atau profitabilitas pada sektor Industri di Kanada dan Malaysia. Pada penelitian di Malaysia, didasarkan pada kuesioner yang sama dengan penelitian serupa di Kanada sebelumnya. Dari hasil kedua penelitian tersebut dapat disimpulkan bahwa terdapat hubungan antara Structural Capital (SC) yang berhubungan positif dengan kinerja perusahaan.

\section{Model 2}

Pada Model 2. Dari hasil analisis yang dilakukan dapat disimpulkan bahwa variabel independen yaitu Value Added Intellectual Coefficient (VAIC) tidak memiliki pengaruh terhadap kinerja perusahaan (ROA). Hal ini tidak sesuai dengan hasil penelitian sebelumnya yang dilakukan oleh Chen et al, (2005) yang mengatakan bahwa jika sumber daya intellectual capital sebagai sumber daya yang sangat bernilai untuk keuntungan kompetitif perusahaan yang akan memberikan kontribusi terhadap kinerja perusahaan.

Tabel 2. Hasil Uji T

Variabel Dependen: ROA

\begin{tabular}{lccc}
\hline \multicolumn{1}{c}{ Variabel Independen } & Koefisien & Sig & Keterangan \\
\hline C & $-0,026$ & 0,470 & - \\
VAIC & $-0,000006251$ & 0,788 & tidak signifikan \\
FSize & 0,006 & 0,011 & signifikan \\
Lev & $-0,011$ & 0,587 & tidak signifikan \\
\hline
\end{tabular}

\section{Model 3}

\section{Tabel 3. Hasil Uji T}

\begin{tabular}{lccc}
\multicolumn{4}{c}{ Variabel Dependen: ROE } \\
\hline \multicolumn{1}{c}{ Variabel Independen } & Koefisien & Sig & Keterangan \\
\hline C & $-0,051$ & 0,587 & - \\
VACA & $-0,00007997$ & 0,121 & tidak signifikan \\
VAHU & 0,006 & 0,005 & signifikan \\
SCVA & 0,039 & 0,061 & tidak signifikan \\
FSize & $-0,002$ & 0,770 & tidak signifikan \\
Lev & 0,281 & 0,000 & signifikan \\
\hline
\end{tabular}

Dari hasil analisis ditemukan bahwa tidak terdapat pengaruh antara Value Added Capital Coefficient (VACA) terhadap kinerja perusahaan (ROE). Hasil penelitian ini tidak sesuai dengan penelitian Dadashinasab (2012). Rehman et. al (2012), Komnenic dan Pokrajic (2012) yang mengatakan bahwa VACA berpengaruh positif terhadap kinerja perusahaan $(R O E)$. Hal ini mengindikasikan bahwa bahwa nilai ekuitas perusahaan yang relatif besar dapat meningkatkan kemampuan perusahaan dalam memperoleh pendapatan. Dengan kata lain, nilai ekuitas perusahaan berkontribusi pada kemampuan perusahaan dalam meningkatkan kinerja perusahaan.

Hasil analisis ditemukan bahwa terdapat pengaruh positif antara Value Added Human Capital (VAHU) terhadap kinerja perusahaan (ROE). Hasil penelitian ini tidak 
sesuai dengan penelitian yang dilakukan Maheran (2009), Chu et.al (2011) yang menunjukkan bahwa Human Capital memiliki pengaruh negatif terhadap ROE. Namun hasil penelitian ini sejalan dengan penelitian yang dilakukan oleh Dadashinasab (2012). Dimana hasil penelitiannya menunjukkan bahwa terdapat pengaruh positif antara $V A H U$ terhadap $R O E$.

Selain itu hasil analisis ditemukan bahwa tidak terdapat pengaruh antara Value Added Structural Capital (SCVA) terhadap kinerja perusahaan (ROE). Hasil penelitian ini tidak sesuai dengan penelitian yang dilakukan oleh Dadashinasab (2012). Namun hasil penelitian ini didukung dengan hasil penelitian yang dilakukan oleh Chen et.al (2005) yang menunjukkan bahwa Structural Capital tidak berpengaruh terhadap ROE. Chen et. al (2005) mengindikasikan bahwa Structural Capital belum mampu memenuhi proses rutinitas perusahaan dalam menghasilkan kinerja yang optimal tanpa diiringi pengelolaan yang baik seperti pengelolaan sistem informasi, prosedur, database yang akan menghambat produktivitas karyawan dalam menghasilkan nilai tambah. Perusahaan belum mampu menciptakan budaya untuk memotivasi karyawan dalam menciptakan budaya untuk memotivasi karyawan dalam meningkatkan kinerja. Perusahaan yang memiliki struktur organisasi yang kuat akan memiliki budaya yang mendukung yang memungkinkan karyawan mereka untuk mencoba hal-hal yang baru, belajar dan dalam praktek mereka (Bontis et.al, 2000).

\section{Model 4}

Tabel 4. Hasil Uji T

Variabel Dependen: ROA

\begin{tabular}{lccc}
\hline \multicolumn{1}{c}{ Variabel Independen } & Koefisien & Sig & Keterangan \\
\hline C & $-0,230$ & 0,002 & - \\
VAIC & $-0,000005314$ & 0,911 & tidak signifikan \\
FSize & 0,018 & 0,000 & Signifikan \\
Lev & 0,212 & 0,000 & Signifikan \\
\hline
\end{tabular}

Dari hasil analisis yang dilakukan dapat disimpulkan bahwa variabel independen yaitu Value Added Intellectual Coefficient (VAIC) tidak memiliki pengaruh terhadap kinerja perusahaan (ROE). Hal ini tidak sesuai dengan hasil penelitian sebelumnya yang dilakukan oleh Chen et al, (2005) yang mengatakan bahwa jika sumber daya intellectual capital sebagai sumber daya yang sangat bernilai untuk keuntungan kompetitif perusahaan yang akan memberikan kontribusi terhadap kinerja perusahaan.

\section{PENUTUP}

Simpulan. Berdasarkan hasil analisis dan pembahasan yang telah dilakukan secara keseluruhan maka disimpulkan mengenai pengaruh dari Value Added Intellectual Coefficient (VAIC) serta komponennya yaitu Value Added Capital Coefficient (VACA), Value Added Human Capital (VAHU), Value Added Structural Capital (SCVA) serta Firm Size dan Financial Leverage terhadap kinerja perusahaan (ROA dan ROE) pada perusahaan Asuransi yang terdaftar di Bursa Efek Indonesia periode 2003-2012 yaitu sebagai berikut: Pertama. (a) ROA. Value Added Capital Coefficient (VACA) memiliki pengaruh signifikan negatif dan Value Added Human Capital (VAHU) memiliki pengaruh 
signifikan positif terhadap kinerja perusahaan, sedangkan Value Added Structural Capital (SCVA), Firm size dan Financial Leverage tidak memiliki pengaruh signifikan terhadap kinerja perusahaan; (b) ROE. Value Added Human Capital (VAHU) dan Financial leverage memiliki pengaruh signifikan positif terhadap kinerja perusahaan, sedangkan Value Added Capital Coefficient (VACA), Value Added Structural Capital (SCVA) dan Firm Size tidak memiliki pengaruh signifikan terhadap kinerja perusahaan. Kedua. (a) ROA. Firm Size memiliki pengaruh signifikan positif terhadap kinerja perusahaan, sedangkan Value Added Intellectual Coefficient (VAIC) dan Financial Leverage tidak memiliki pengaruh signifikan terhadap kinerja perusahaan; (b) ROE. Firm size dan Financial Leverage memiliki pengaruh signifikan positif terhadap kinerja perusahaan, sedangkan Value Added Intellectual Coefficient (VAIC) tidak memiliki pengaruh signifikan terhadap kinerja perusahaan.

Implikasi Manajerial. Berdasarkan hasil penelitian ini diharapkan dapat dijadikan masukan bagi manajer perusahaan dan juga oleh para investor. Adapun implikasi manajerial dari penelitian ini adalah sebagai beriku: Pertama. Bagi Perusahaan. Bagi manajer keuangan harus dapat mempertimbangkan faktor Value Added Intellectual Capital (VAIC) serta komponennya yang meliputi Value Added Capital Coefficient (VACA), Value Added Human Capital (VAHU) dan Value Added Structural Capital (SCVA) dalam mengelola Intellectual Capital secara lebih baik dalam menentukan keputusan yang tepat dan untuk menciptakan keunggulan bersaing serta meningkatkan kinerja perusahaan yang akhirnya dapat menciptakan laba serta produktivitas yang optimal bagi perusahaan. Kedua. Bagi Investor. Hasil penelitian ini dapat digunakan bagi investor sebagai pengukuran kinerja yang berbasis ROA dan ROE. Investor dapat mempertimbangkan untuk melakukan investasi yang lebih tinggi atas saham perusahaan yang memiliki intellectual capital yang lebih dibandingkan perusahaan dengan intellectual capital yang rendah.

Saran. Berdasarkan hasil penelitian ini, maka saran yang diberikan untuk penelitian selanjutnya adalah sebagai berikut: (1) Penelitian selanjutnya diharapkan menambahkan objek penelitian lainnya; (2) Sebaiknya penelitian selanjutnya menambahkan varabel dependen lain seperti Productivity Performance (ATO) dan market Valuation Performance $(M B)$

\section{DAFTAR RUJUKAN}

Ahmed, N., Ahmed, Z. and Usman, A. (2011) "Determinants of Performance : A Case of Life Insurance Sector of Pakistan, International Research Journal of Finance and Economics, 61, 123-128

Anshori, M. And Iswati, S (2007) "The Influence of Intellectual Capital to Financial Performance at Insurance Companies in Jakarta Stock Exchange (JSE)," Paper presented at 13th Asia Pacific Management Conference, Melbourne

Almajali, A.Y., Alamro, S.A. and A-Soub, Y.Z. (2012) "Factors Affecting The Financial Performance of Jordanian Insurance Companies Listed at Amman Stock Exchange", Journal of Management Research, 4 (2), 266 -289

Bontis, N. (1998) "Intellectual Capital: An Exploratory Study That Develops Measures and Models, Management Decision, 36 (2), 63-76 
Bontis, N., Chua, W., Keow, C. and Richardson, S. (2000) "Intellectual Capital and Business Performance in Malaysian Industries", Journal of Intellectual Capital, 1 (1), 85-100

Brigham, E. And Houston, J. (2010) Essencials of Financial Management (2 ${ }^{\text {nd }}$ Edition), Nelson Education

Bueno, E., Salmador, M.P., Rodriguez, O and de Castro, G.M. (2007) "Internal Logic of Intellectual Capital : A Biological Approach”, Journal of Intellectual Capital, 7 (3), 394-405

Cabrita, M.R and Bontis, N (2008) "Intellectual Capital and Business Performance in The Portuguese Banking Industry", International Journal Technology Management, 43 (1-3), 212-237

Canizares, S.M.S., Munoz, M.A.A. and Guzman, T.L. (2007) "Organizational Culture and Intellectual Capital: A New Model”, Journal of Intellectual Capital, 8 (3), 409-430

Chan, K.H. (2009) "Impact of Intellectual Capital on Organisational Performance, an Empirical Study of Cmpanies in the Hang Seng Index (part 1)", The Learning Organization, 16 (1), 4-12

Charumathi, B., (2012) "On The Determinats of Profitability of Indian Life Insurers- an Empirical Study, Proceeding of The World Congress on Engineering, 1

Chen, M.C., Cheng, S.J.\& Hwang, Y (2005) "An Empirical Investigation of Relationship Between Intellectual Capital and Firms Market Value and Financial Performance", Journal of Intellectual Capital, 6 (2), 159-176

Cheng, M.Y., Lin, J.L., Hsiao, T. and Lin, T. W. (2010) "Invested Resource, Conpetitive Intellectual Capital, and Corporate Performance", Journal of Intellectual capital, 11 (4), 433-450

Chu, P.Y., Lin, Y.L., Hsiung, H.H. and Liu, T.Y (2006) Intellectual Capital: an empirical study of ITRI", Technological Forecasting \& Social Change, 16 (1), 4-21

Chu, S.K.W., Chan, K.H. and Wu, W.W.Y. (2011) "Charting Intellectual Capital Performance of The Gateway to China," Journal of Intellectual Capital, 12 (2), 43350

Cohen, S. And Kaimenakis, N. (2007) "Intellectual Capital and Coporate Performance in Knowledge-Intensive SMEs", The learning Organization, 14 (3), 241-262

Crossan, M.M., Lane, H.W. and White, R.E. (1999) “An Organizational Learning Framework: From Instiuition", Academy of Management Review, 24 (3), 523-537

Dadashinasab, M., Sofian, S., Asgari, M. and Abbasi, M. (2012), "The Effect of Intellectual Capital on Performance : A Study among Iranian Automotive Industry," Journal of Basic and Applied Scientific Research, 2 (11) : 11353-11360

Despres, C. and Chauvel, D. (1999), "Knowledge management(s)", Journal of Knowledge Management, 3 (2) : 110-120

Enrhardt, L. (2007), "Intellectual Capital : The New Competitive Advantage “, Management Today : 50-52

Firer, S. \& Williams, S.M. (2003) Intellectual Capital and Traditional Measures of Corporate Performance, Journal of Intellectual Capital, 4 (3) : 348-360

Fornell, C. (2000), Customer Asset Management, Capital Efficiency and Shareholder Value", Proceedings of The Performance Measurement, Past, Present and F uture Conference, Cambridge University, UK, 20 July 2000, available at: www.cfigroup.com/resources/articles/claes.pdf 
Flamini, V., McDonald, C. and Schumacher, L. (2009), "Determinants of Commercial Bank Profitability in Sub-Saharan Africa", Working Papers (19) : 15, International monetary Fund, Washington, DC

Gitman, L. and Zutter, C. (2015), Principles of Managerial Finance (14 ${ }^{\text {th }}$ Edition). Boston: Pearson Education,Inc

Goh, P.C. (2005) "Intellectual Capital Performance of Commercial Banks in Malaysia," Journal of Intellectual Capital, 6 (3), 385-396

Grant, R.M. (1996), "Toward A Knowledge-Based Theory of The Firm," Strategic Management Journal, 17 (7), 109-22

Grasenick, K. And Low, J. (2004) "Shaken, Not Stirred, Defining and Connecting Indicators for the, Measurement and Valuation of Intangibles," Journal of Intellectual Capital, 5 (2), 268-281

Kamath, B.G. (2007), "Intellectual Capital Performance of Indian Banking Sector", Journal of Intellectual Capital, 8 (1), 96-123

Kamath, B.G (2008), "Intellectual Capital and Corporate Performance in Indian Pharmaceutical Industry", Journal of Intellectual Capital, 9 (4), 684-704

Kang, S.C. and Snell, S.A (2009), "Intellectual Capital Arctectures and Ambidextrous Learning: A Framework for Human resource Management", Journal of Management Studies, 46 (1), 65-92

Kujansivu, P. and Lonnqvist, A. (2007), "Investigating The Value and Efficiency of Intellectual Capital", Journal of Intellectual Capital, 8 (2), 272-287

Kim, D.H (1993), “The Link Between Individual and Organizational Learning," Sloan Management Review, 35 (1), 37-50

Khrawish, H.A and Kraiwesh, A.H.A (2010), The Determinants of The Capital Structure: Evidence From Jordanian Industrial Companies, JKAU: Econ and Adm, 24 (1), 173 96

Khrawish, H. A. (2011) "Determinants of Commercial Banks Performance: Evidence From Jordan", International Research Journal of Finance and Economics, Zarqa University, 5 (5), 19-45

Komnenic, B. and Pokrajic, D. (2012) "Intellectual Capital and Coporate Performance of MNCs in Serbia, Journal of Intellectual Capital, 13 (1), 106-119

Maheran, N. and Muhammad ,N. (2009) "Intellectual Capital Efficiency and Performance : Study on Malaysian Financial Sectors", International Journal of Economics and Finance, 1 (2)

Marr, B., Schiuma, G. and Neely, A. (2004) "The Dynamics of Value Creation: Mapping Your Intellectual Performance Drivers", Journal of Intellectual Capital, 5 (2), 312325

Mehari, D. and Aemiro, T. (2013) "Firm Specific Factors That Determine Insurance Companies' Performance in Ethiopia, European Scientific Journal, 9 (10), 245-255

Montequin, V.R., Fernandez, F.O., Cabal, V.A. and Gutierrez, N.R (2006) "An Integrated Framework for Intellectual Capital Measurement and Knowledge Implementation in small and medium-sized enterprises", Journal of Information Science, 32 (6), 525538

Moon, Y.J. and Kym, H.G (2006) “ A Model For The Value of Intellectual Capital”, Canadian Journal of Administrative Sciences, 23 (3), 253-269 
Mouritsen, J., Larsden, H.T. and Bukh, P.N.D (2001), "Intellectual Capital and The Capable Firm : Narrating, Visualising and Numbering for Managing Knowledge", Accounting, Organizations and Society, 26 (7), 735-762

Organization For Economic Cooperation and Development (2001), The well-being of Nations: The Role of Human and Social Capital, Centre for Educational Research and Innovation, OECD, Paris

Pablos, P.O.D. (2005) "Intellectual Capital Reports in India: Lessons from a Case Study," Journal of Intellectual Capital, 4 (1), 61-81

Pulic, A. (1998) "Measuring The Performance of Intellectual Potential in Knowledge Economy," available at :www.measuring-ip.at/Opapers/Pulic/Vaictxt.html (accessed 7 march 2011)

Pulic, A. (2000) "VAIC-an accounting tool for IC Management," International Journal of Technology Management, 20 (5-8), 702-14

Reed, K.K., Lubatkin, M. And Srinivasan, N. (2006) "Proposing and Testing an Intellectual Capital Based View of The Firm," Journal of Management Studies, 43 (4), 867-93

Rehman, U.W., Rehman, U.H., Usman, M. and Asghar, N. (2012) “A Link of Intellectual Capital Performance With Corporate Performance: Comparative Study From Banking Sector in Pakistan," 3 (12) [Special Issue - June 2012]

Roos, G. and Roos, J. (1997) "Measuring Your Company's Intellectual Performance," Long Range Planning, 30 (3), 325

Sangkala. (2006) Intellectual Capital Management. Jakarta : Yapensi

Schiuma, G., Lerro, A and Sanitate, D. (2008) The Intellectual Capital Dimensions of Ducati's Turnaround: Exploring Knowledge Assets Grounding A Change Management Program," International Journal of Innovation Management, 12 (2), 161-93

Stewart, T.A (1997) Intellectual capital: The New Wealth of Nations, Doubleday Dell Publishing Group, New York, NY

Subramaniam, M. And Youndt, M.A. (2005) "The Influence of Intellectual Capital on The Types of Innovative Capabilities," Academy of Management Journal, 48 (3), 450 63

Taswan, (2010) Manajemen Perbankan: Konsep, Teknik dan aplikasi, Edisi 2, Yogyakarta: UPP STIM YKPN

Ting, I. W. K and Lean, H.H (2009) "Intellectual Capital Performance of Financial Institutions in Malaysia", Journal of Intellectual Capital, 10 (4), 588-599

Undang-Undang 1992, Undang-Undang No. 2 Tahun 1992 Tentang Usaha Perasuransian

Watson, A. And Stanworth, J. (2006) "Franchising and Intellectual Capital: A Franchisee's Prespective," Entrepreneurship Management, 2 (3), 337-49

Zeghal, D and Maaloul, A (2010) "Analyzing Value Added as an Indicator of Intellectual Capital and its Consequences on Company Performance, Journal of Intellectual Capital" , 11 (1), 39-60 